\title{
学会記事 Newsletter
}

\section{I. 会則等検討委員会中間報告}

会則等検討委員会は，松永英会長の諮問委員会として 1988 年 9 月 9 日に発足し，下記の諮問事項 について答申するなら求められた。

1. 理事長制度導入の可否を含めて, 本学会会長 (をたは理事長) の選び方，任務と任期等につい $\tau$.

2. 日本学術会議に推薦すべき会員候補者和よびその推薦人ならびに研究連絡委員会の委員候補 者の選び炈て.

3. その他, 学会運営上の重要事項について.

これにより，委員会を 3 回開いて審議を行い，1989年 8 月 25 日付で中間報告を提出した. 理事会 で審議の結果, 中間報告の内容を下記のように整理して評議員会に報告することになった。

\section{報 告 内容}

現行の日本人類遺伝学会会則を検討した結果, 全般的によく機能して括り, 基本的には部分的な変 更を加えるだけでよいと考乒た.

現行会則の変更案を理由を付して（別紙の）刘照表に示した。

ただし，第十一条は会長，理事など役員に関連した内容からなり，その変更については今後さらに 検討を継続する必要が方ると考克られるので，審議された事項を以下に示し，それ対する判断は理 事会に一任することとした。

1. 役員について

評議員, 理事, 幹事の任期, 選出方法, 任期, 業務などについては, 現行の規則を変更する必要 性は認められなかった。

2. 会長, 理事長飞ついて 本学会の代表者として会長，理事長のいずれが適切であるかについて検討し，選出方法等につい ても討議を行った，検討した内容は下記のと赦りである。

A. 現行のまをとする.

B. 理事長制を導入する.

理事は実務執行の任務に当たり，理事長は執行部の代表者として学会を代表する性格を有す 当.

現行の規則では理事の任期は 4 年で， 2 年ごとに半数改選があり，重任は認められていない. 理事長の任期については, こ齐に 2 年とし, 理事在任中の再任を妨げないと規定すると無理が生 じない.

理事長恃理事の中から選出されることになるが，その選出手続として，理事の互選，評議員に よる選出，会員による選出のいずれかが考えられる.

C. 会長制を改める場合.

現在の本学会は会長制を採って扬り，会長は理事会を招集し，重要案件を諮問し，かつ学会を 代表する立場に㘯る。したがって，会長は理事会から独立した存在としてとら光られる，その意 味に打いて，会長は理事とは異なったプロセスで選出されるべきであるとする意見が出された。

その選出手続として, 理事会での選出, 評議員による選出, 会員による選出が考觉られる、ま 
た，手続として会長候補者若干名をあらかじめ指名してからの投票も考光られる。

3. 地区沉つて

評議員の選出伎現在 7 地区に分けて行われているが，地区の会員数に著しい差があるのて，地区 の編成の变更について検討した。しかし，現行規則の变更索必要とする理由心見当たらない上の結 論に達した。

4. 第十一条の取扱いについて

現行の第十一条你，上記の問題点に対しての基本的な万針が示された段階に告いてさらに検討 し，必要に応して条文の修正案を作成する，季た，本条は長文であるので，二つ以上の条文に分け ることを考えるとよい。

5. 候補者などの選出について

談問事項に述べられた日本学術会議の会員候補者，その推薦人，研究連絡委員会の委員候補者の 選出は理事会で行うのが妥当であると考员た。

1989 年 9 月 30 日

日本人類遺伀学会・会則等検討委員会

岡島道夫 (委員長)，今村 孝，黑木良和，笹月健彦，

外村 晶, 松井一郎, 三輪史朗

新旧会則対照表から，今回変更されることになった条文と変更個所（下線部）だとと以に示す。

第三条 本会は事務所它東京都文京区湯島 1 丁目 5 番地 45 号 查京医科歯科大学難治疾患研究所 遺伝疾患研究部門に拈く。

第四条人類遺后の研究に從事し，またはこれに関心を有するすので，評議員の推鹿得たものは 本会に入会することができる.

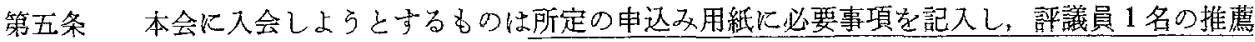
状と当該年度会費を添党て本会の事務連絡先：東京都文京区弥生 2-4-16（テ 113）旦本学 会事務センターに提出する.

第六条会員は個人会員，機関会員扣よび維持会員とする．個人会員は名誉会員和よび普通会員と する．年会費として普通会員と機関会員は金 5,000円，ただし在学証明曺を提出したとき

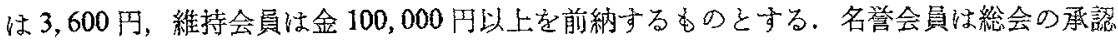
を経て会長が依嘱する，名䇾会員の会費は䍊収しない。

第十条（削除）

第十一条（第十条とする）

第十二条（第十一条とする） 本会の尋務年度は1月1日より12月31日吉でとする.

(1989年10月 26 日改正)

(会則等検討委員会委員長 岡島道夫)

\section{II. 日本学術会議「ヒト・ゲノム・プロジェクトの推進について (勧告)」}

去亏11月28日日本学術会議遺伝医学研究連絡委員会開催の折, 井上英二委員長より経過説明があ った．本学会にとって大切な事項と思われるので揭載する。

（遗伝医学研連幹事 三輪史朗） 
内閣総理大臣 海部俊尌殿

総学庶第 877 号 平成元年 10 月 19 日

日本学術会議会長 近藤 次蚛

\section{ヒト・ゲ/ム・プロジェクトの推進について(勧告)}

漂記につけて，日本学術会議第 108 回総会の議涣に基づき，下記のと抢り勧告します。

記

ヒト・ゲノムの全 DNA 塩基配列決定を主たる目標とするとト・ゲノム・プロジェクトは，関㨁 墸分野の学術研究に極めて大きなインパクを与克ると期待され，我が国として早急かつ重点的に推 進すべきでする。

そのためには，ヒト・ゲノム・プロジェクト推進組織（仮称）を設け，基本計画の立案，実施計画 の策定, 省庁間などの協議, 国際協力, データ・ベースとレポジトリーの整備などを総合的に行うべ きである。

また，この推進組織との密接な連携のもとに，研究計画の実施に伴う社会的, 法律的及び倫理的諸 問題を客観的かつ公正に判断するとともに，これらの諸問題に適正に対処することを目的とするプロ ジェクト・チェック機構（仮称）を設立し，全体として調和のとれた施策を進める必要がるる。

よって，日本学術会議は我が国に和ける本プロジェクトの推進を图り，そのため必要な措置を講 ずるよう勧告する.

本信送付先：内閣総理大臣

本信写送付先 : 外務大臣, 大蔵大臣, 文部大臣, 厚生大臣, 農林水産大臣, 通商産業大臣, 科学技 術庁婹官

[説明]

I 前置き

ヒト・ゲノム・プロジェクトは，その一部に遺伝子を含むヒト・ゲノムの全 DNA 塩基配列を決 定し，七下遗伝子及び DNA 断片が染色体上に占める位置の決定並びに実験動植物に和讨る比較研 究及び関連技術の開発とあいほって，人類の持つ遺伝情報の解読之遺伝子機能の解明を飛躍的に進め ようと寸る一大研究計画である. この研究計画注 1986 年以来アメリカ合衆国, 日本，ヨーロッパ諸

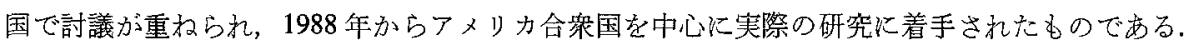

このプロジェクトがもたらすと期待されるインパクトは極めて大きく，我が国として早急にから重 点的に推進すべき重要研究課題である. 一方, これによって人間社会は様々な影響を受けると予想さ 机ることから，その推進炕当えっては，このよらな二側面を総合的汇勘案し，格段の配慮を厸いつ つ，調和のとれた施策を進めなければならない。

\section{II ヒト・ゲノム・プロジェクトの推進}

ヒト・ダノム・プロジェクトは, 広く基礎生物学, 生化学, 生理学, 医学, 苩学, ロボット工学, 情報処理なと゚の学術研究領域汇極めて大きなインパクトを与えるであるうと期待され，我が国として 早急かつ重点的に推進すべきである，それがもたらすと期待される成果の中には，人類の遺伝的プロ グラムの解明, 遗伝怪疾患対策の飛躍的向上, 未知の生理活性物質の発見, 塩基配列分析ロボットや 大量の情報処理技術の開発などが含まれる.ささらに，このプロジェクトによって生命科学, 生命工学 並びに関遇領域の技術開発が進めば，多くの科学分野の発展を促し人類福祉比貢献することは疑いな いところである。

Vol. 34, No. 4, 1989 


\section{III ヒト・ゲノム・プロジェクト推進組織（仮称）の設立}

このプロジェクトの大部分は現在の技術によって原理的に遂行可能でするが，当面の課題は，研究 遂行のための莫大な経費と完成まで長期間を要するといら险路を克服することである。この儖路を 克服し，ヒト・ゲノム・プロジェクトを推進するためには，関連省庁，多種多様な研究機関，多岥 に亘る専門分野の研究者々关の集団は，研究課題の選定などについて密接な連携を保ち，施設，労 力，経費などの效率的な運用を图らなければならない，そのために第一に着手すべさことは，ヒト・ ダノム・プロジゥク老総合的に推進する組織,すなわちヒト・ゲノム・プロジェクト推進組織（仮 称）の設置である.

このヒト・ゲノム・プロジェクト推進組織(仮称)の主たる目的は以下の上蛙りである。

1 プロジニクト全般に亘る基本計画を立案すること。

2 基本計画化基づく実施計画学策定すること.

3 研究遂行のために省店及び研究機関, 研究者の間の相互の連絡及び協議を行うこと.

4 このプロジェクトに関する国際協力の空口としての役割を担らこと.

5 DNA，細胞などの保存供給施設（いわゆるレポジトリー）の設立及び整備に係わる問題に対処 すること.

6 データベースの技術開発及びデータの蓄積, 評価, 提供の推進に倸わる問題に対処すること.

これらのらち，国際協力に関して様々な経路を通じてすでに我が国烧する打診が進められてお り，光の協議先としては外国政府，ECなどの泳か，HUGO (Human Genome Organization) のよ うな民間団体が予想される。高た，レポジトリ一を国際組織の一環とするか否か，一環とする場合ど のよう《分担をするかなどの検討もこの推進組織の任務である.

このヒト・ゲ/ム・プロジェクト推進組織（仮称）は, 研究の進展に弾力的かつ機動的に対処でき るすのとしなければならない，また，この組織には研究遂行に伴う具体的問題の処理に当たるため， 各省庁の生命科学，生命工学担当者のほか，関連領域の尃門家によって構成される委員会等を設ける

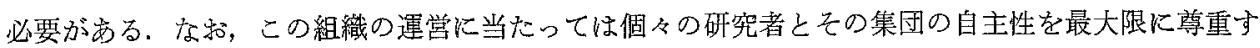
べきととはいら李でるない。

\section{IV プロジェクト・チェック機構（仮称）の設立}

他面このプロジェクトは，以下のように人間社会に詨し様々な影響安及ぼすであるらと予想されて いる。すなわち，研究に用いる検体を提供する人のインフォームド・コンセント（説明を受けた上で の同意)，プライバシー，コンフィデンシテリティー(職業上の守秘義務) の問題や，情報の管理の問 題, 研究計画と成果の公開の問題, 研究材料と成果の知的所有権の問題など, プロジェクト飞直接由 来する社会的，法律的諸問題の注が，研究成果の応用に際しての柡々な倫理的問題がある.

このブロジェクトの実施に伴って生じる社会的, 法律的及び倫理的諸問題に適切に対处するために は，前記のヒト・ゲ/ム・プロジェクト推進組織(仮称)と並んで，プロシェェクト・チック機構

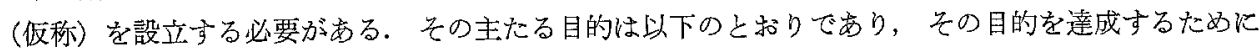
必要な権限が与完られるべきである。

1. インフォームド・コンセント，プライバシー，コンフィデンシフリティーの磪保など, 榆体提 供者の保護のための基準を作成すること。

2. 情報の管理，研究計画と成果の公開の基準を作成すること.

3. 知的所有榷問題についての方針を作成すること.

4. 研究成果の忘用段階飞たける偷理的問題飞ついての指針を作成すること.

以上のらち榆体提供者の保護と情報の管理並びに公開については，遅くともプロジェクトの発足と 
並行して検討を開始し，できるだけ早期炕基準を示すことが必要である。それでれの研究機関は，機 関内審查委員会を設立し，この基準に基づいて具体的問題の処理に当たるべきである。 また，知的所 有権問題は，このプロジェクトの進行に伴って，多かれ少なか秃成果が挙壮られることは疑いないと ころで西るから，研究材料そのもの，あるいはその解析によって得られるとトの生命機能隹関する膨

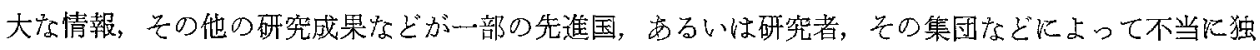
占されることを避りるため，我が国としての方針を緊急泆定し度ければならない。

香た，プロジェクト・チェック機構（仮称）のメンバー性，いやしくも人間性の根本に倸わる生命 の人工的操作などが行われることのないよう，ヒト・ゲノム・プロジェクト推進組織（仮称）と密接 な連携を保らつつ, 研究計画の当否を客観的かつ公正に判断しな计ればならない,メンバーの構成と しては，このブロジェクトに直接関連する領域以外の研究者などを主とし，かつ，推進組織の構成員 と重複しないことが望ましい，日本学術会議が候補者の推薦に当たるのも一法で㟧る。

\section{$\mathrm{V}$ 結 び}

以上のごとく日本学術会議は，ヒト・ダノム・プロジェクトの推進並び比ト・グノム・プロジェ クト推進組織(仮称)及びプロジェクト・チェック機構(仮称) の設立に倸わる勧告を行うるのである.

III. わが国の上トゲノム・プログラム推進グループ代表：松原謙一博士より淞永英会長に届いた， 本プロジェクト成立までの経䋨子当面の目標，扣よび将来の計画についての文書を揭載する．広く

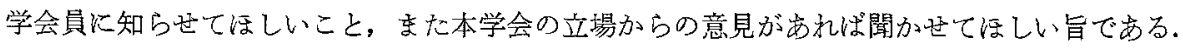

(編策委員長 三輪史朗)

\section{ヒトゲ/ムの解析を学際協力研究で}

\section{一日本におけるヒトゲノム解析プログラムの進め方について-}

1970 年代飞遺伝子のタローニングと DNA の塩基配列決定技術が開発され普及してから，生物学 は大きく変わりました，多細胞生物の研究，なかでもとトの研究が急速に進み，これまで你析され た数百の遗伝子の情報からだけでる，上卜の生物学的理解は格段飞深栾り至した，今後，発生・分化 や脳神経など高次の生命現象の研究，さらには，生態系での生物相互の関係なぞの研究が進むことが 期待されますが，遗伀子の解析はとれらの研究を支党るすのとしても，ますます必要になるでしょ 5 .

そのような研究の流れの中で，生物のゲノムDNAの全搆造を解析し，そこに含まれている遺伝 情報のすべてを解読しょうという計画が動き始めました。なかでもとトゲノムを解析する訫画が各国 で軌道に乗り始めています。研究の国際的な協調・調整をはかる機関 HUGO (Human Genome Organization）る設立されました。これらの計画の進展は，生物科学の研究を発展させるだけでなく， 生物系がるつ大量の情報の处理や，その解析を中心として情報科学の新しい分野を産出出可可能性が

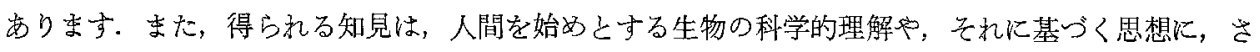
らには，その医学や産業への応用比，画期的なインパタト考与光ると期待されています。

しかし，大きなダノム（ヒトの場合，約 30 億塩基詨のDNA，5２0万万の遺伝子）を解析し，包括 的理解を目指すには，現在のDNA 研究技術を基盤に，ただ労力をがするだけで泩目的は達せられ ま世ん，新しい思考法や方法論の飛躍的な展開，さらに，大量情報の処理・解析システムの開発など

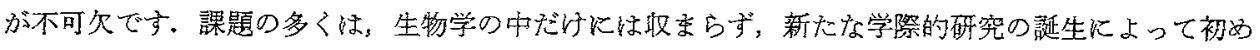
て解決が可能なるのです. 


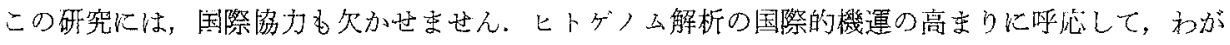

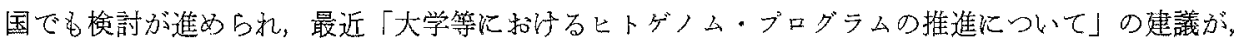
学術審議会からだされるした注)。こ礼受けて文部省は平成元年度より2 年間, 総合研究 (A)「七卜 ゲノム・プログラムの推進に関する研究了(代表者・大阪大学細胞工学センター・松原謙一) 発足さ

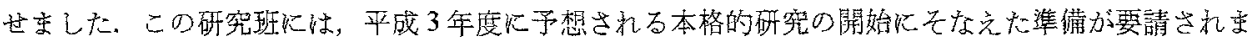
した。

準備的研究の 2 年間について私たちは，ゲ，ムの構造々機能の解明に焦点を当てた遺伝情報の全体 像を理解するこ之を最終目的之して，上卜を含む多くの生物種化ついてのダ，ムの分子生物学的研究

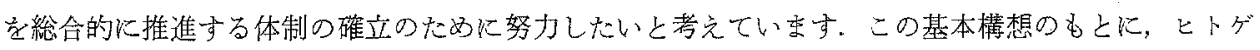
，ムについてはその医学的意義の重要性と国際協力の要請を考慮して，遺伝子の同定，マッピング,

構造決定，及び各種の機能領域の解析を中心とした研究を重点的に推進し，一方では，巨大ゲ/ムの

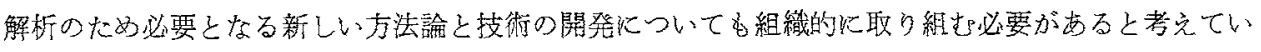
ます。

こらした考え方に立って, 当面下記のように準備的研究を進めて行く予定です.

\section{I . 当面の研究課題}

1) とト・ダノムの解析、ヒトゲ，ムの遗伝学的まよび物理的地図の作成，そこに分有する遺妘子 や各種機能単位の同定，個別遺伝子の塩基配列決定，さらにダ/ム解析の優札た原理や方法論の開発

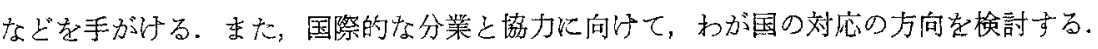

2） CDNA ライブラリーの作慗. ヒト・ゲノムDNA のなかで蛋白質にコードされる領域の構造 を解明すること以極めて重要である。ヒトゲノム・プログラムの推進に対応でさるよう, 組織・器占 の cDNA ライブラリーを作慗し，その整理・解析を目摽之した研究を行う。

3) DNA 解析技術の開発。見在のDNA 解析技術だけでは，巨大ゲ/ムの全構造に迫るこ上は難 しい, 染色体や巨大 DNA の分離, DNA の任意位置切断, 長鎖 DNA のクローニング, クローン の安定保持，長距離シークエンシングなどの課題について，改良を開発に関わる研究を行う。

4）大量情報処理系の開発. 各種生物の染色体の遺伝子地図ら゙くりやDNA 塩基配列デーダベー スの满築などが国際協力体制の下潐るられているが，巨大ダノムの DNA 水準での解析が軌道にの

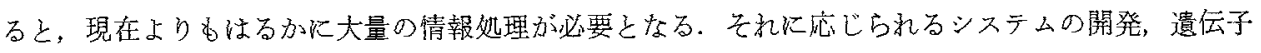
地図・物理地図・塩基配列の一本化の試歹，生物種間を連携させたデータベースの構筑，新情報の解 㜔などを目指した研究を行う。

5) 各種生物ダノムの解析，ヒト・ダノムの解析は各種生物のダノム解析と並行して進むことが乗 要である、新しい技街やダノムの構造・機能の知見などを交流しつつ同調して研究が進行するように 因々。

\section{II. 将来計画の策定}

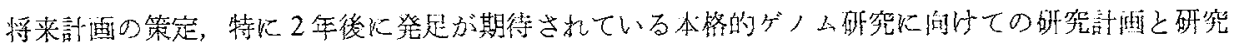
組織の確立が要望されている，そこで必要な意見を広く取りまとわ，討論の資料として提出する．ま た，これ必要な研究環境を整備し，国際協力の要埥に対伈できる国内の体制をつくることに協力す る.

注この活かに，学術会議・生命科学と生命工学特別委員会報告“ヒトゲノム・プロジェクトの推 進について”，科学技術庁・航空電子等審議会答申 “七ト遺伝子解析化関する総合的な研究開発の推 進方策についでがあり，それぞれ研究の早急な推進を提案し，からそのさい考虑すべき問題点など を馀じてい沓ず. 
本研究が着実に進展し，わが国の基礎研究の発展のために有益な役割孝果たすためには，生物ゲ， ムの研究者はもちろん, 広く生物学, 遺伝学, 医学, 農学, 物理学, 化学, 工学, 情報科学などの領 域の研究者の協力が必要となります，そのために，巨大ダノム解析のための研究への直接参加はもと より，基盤研究にも参加し，協力下さることを期待いたします。

な括, この総合研究班は, 上記の研究を当面 2 年の目標で進め, 2 年後に発足が期待されている七

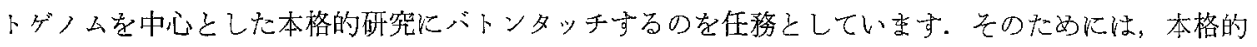

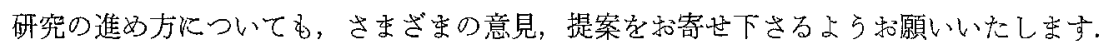

1989 年 10 月

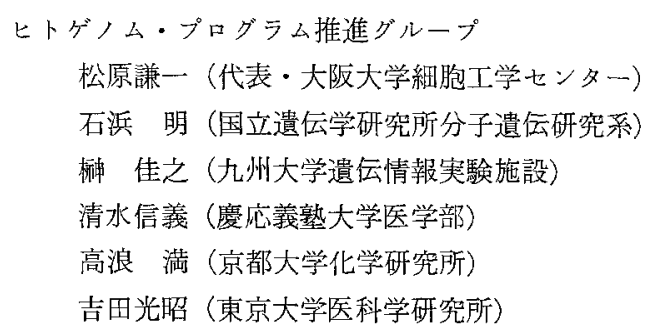




\section{IV. 日本学術会議だより No.15

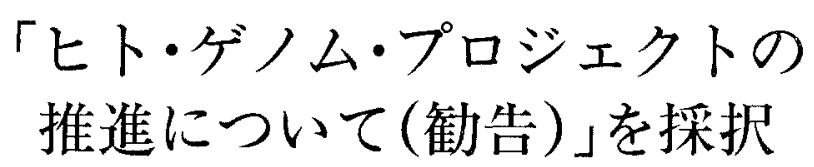

平成元年11月日本学術会議伀報委員会

日本学術会議は、去る10月18日から20日まで第108回総会（第14期 4 回目の総会）を開催しました。今回の日本学術会 議だよりでは，その総会で採択された勧告を中心に，闹総会の議事内谷等について，お知らせいたします。

\section{日本学術会議第108回総会報告}

第 108回総会の主な議事概要は次のとおりであった。

第1日（10月18日）の午前。まず，会長から，前回総会 以後の経過報告が行われ、続いて，各部・委貨会の報告か 行われた。さらに、今回総会に提案されている3案件につ いてそれぞれ提案説明がなされた後，貿疑応答が行われた。

第1日の午後。各部会が開催され，午前中心提案説明さ れた総会提案案件等の番議が行っれた。

第2日（10月19日）の午前。前日提案された案件の憲議 採決が順次行かれた。

まず，第 7 部の専門別の会員定数の変更並しに同部世話 担当の研究連絡委員会の再編成（統合 3 件，分割 2 件，新 設 1 件，名称変更 6 件）を内容と寸る，会則の一部改正が 採択された。

続いて，第 4 部及び第 7 部の「会員の推麅に俰る研究連 䅂委員会」の指定の変更を内容とする, 関係規則の一部改 正が採択された。

これらの改正は，具体的仁は第15期加放の組織・活動に 倸るものである。

号らに,生命科学と生命工学特別委員会の提案による「匕 ト・ゲノム・プロジェクトの推進について(勧告)」が採択 された。なお，この件の審諉の際には，研究成果公開の原 則とプライバシ一保護等の問題「プロジェクト・チェック 機構(仮称〉」の果たす具体的役割等について, 討議が行わ れな。この勧告は, 同日午後直ちに内閣総理大臣に提出さ

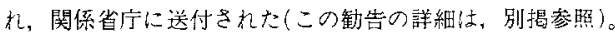
また，本総会に㧍いては，会長から，日本学術会議の移 転問題に関し，前回総会以降の主な動きとして，(1)去る8 月「国の行政機関等移転推進連絡会議」において，本会議 の移転先が横浜市「みなとみらい21地区」となったこと， (2)これに对し三役及ひ運営番議会のとった对応，などにつ いて報告があった。種々質疑応答が行われた後、これまて の三役及び軍営憲議会の対応については，基本的な了承か なされた。また，今後の移転に関す当諸䦓題については， 当面、三役及じ運営審議会にその処理を一任することで了 承された。

第 2 日の午後。「地球環境問題」について，活発な自由討 議が行われたにの自由討議の詳細は、別揭参照)。

第3日 $(10$ 月20日) 午前には各常置委員会が，午後には 各特別委員会が，それぞれ開催されさ。

\section{ヒト・ゲノム・プロジェクト の推進について（勧告）}

\section{(勧篞本文)}

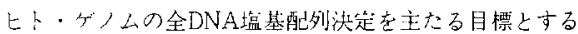
ヒト・ゲノム・ブロジェクトは, 関連諸分野の学術研究に 極为て大きなインバタトを与えると期待され，我が国とし て早急加つ重点的倠進す心きでる。

そのためには、ヒト・ダノム・プロジエタト推進組織(仮 称）を設忛，基本計画の立案，実施計画の策定，省序䦗な どの協議。国際協力、データ・ベースとレポジトリーの整 備などを棇合的に行うべきである。

またここの推進組織との緊密な連携のもとに，研究計画 の実施に伴う社会的，法律的及U゙倫理的諸問題を客観的か つ公正に判断するとともに、こ礼らの諸問題に適正に対処 することを目的とするプロジェクト・チェッ機構(仮称) を設立し全体として瀷和のと机た施策を進める必要がある。 よって，日本学術会議は我が国に打沙る本ブロジエクト の推進を図りそのた的必要な措置を講ずるよう鹳告する。 (説明) [要旨]

1 上卜・ゲ/ム・ブロジェクトは，人類の遺佉情報の解 読と遺伀子機能の解明定目指しな研究計画であり，早急 がつ重点的に推谁寸べきで古る。このプロジェクトによ つて生命科学等の領域の技術開発が進めば，人類福祉に 嘪献することは疑いない。

2 上卜・ゲノム・ブロジェタトを推進するために，上卜 ・ゲノム・プロジェクト推進組織(仮称)を設置する。 その主たる目的は勧告本文のとおりである。

この組織は，研究の進展に弾力的に対処できるものと し，具体的問題の処理のため委買会等を設ける。運営に 当なっては個々の研究者上その集団の自主性を最大限に 尊重すべきである。

3 このプロジェクトの実施に伴って生じる社会的, 法律 的及び倫理的諸問題に適切に对処するために，プロジ工 クト・チェック機構(仮称) 衣設立する。その主たる目 的は，検体提供者の保護のための基準を作成すること， 情報の管理，研究計画と成果の一般への公開の基染を作 成すること，知的所有権問題についての方針を作成する こと, 研究成果の応用段階に打计る倫理的問题について の指針を作成することであり，目的達成のための必要な 権限が与えられるべきである。 


\section{総会中の自由討議一地球環境問題一}

本会議総会中の重要な行事である, 自由討議が, 綕会 2 日目の10月19日の午後 1 時加ら 3 時間にわたって開催呈れ た。この総会中の自由討議は，会員のための一種の魅強会 でその時々の学術上の重要課題を取り上げて行われてい る。今回は「地球瞅境問題」という課題のもとに行少れた。 自由討議は，渡䢞格副会長の司会のもとに，5人の会員 による意兒発表が市り，名らにこれらの意見発表をもとに 会員閒で活発な討崢が行われた。

今回の自由討議の慨要は次の上おりである。

[5人の会員による意見発表

ま劣，近藤次郎第 5 部会貝加占，9月の「地球環境保全 汇関する東京会議」の出席報告として，(1)罢境保全と発展 途上国の資源開発，産業振與等との関初りについての討㖣 状涚，(2)ソ連における瓄境间題，(3)大気中の炭酸がスの增 加に伴う温暖化による地球噮境への影響に関する注目す心゙ き研究結果の発表等について紹介が苛った。

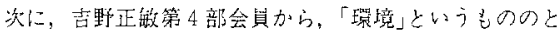

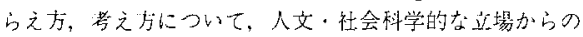
例をも引いて意兒が述べられまたＩGBPについて，同計 画は，桪々な環境問題を基礎科学分野としてとらえるもの であり、その奏施の結果, 直ちに, 噮境閣題が全て明らか になる砉のていない等の発言があった。

次いで，大谷茂盛第 5 部会員から，同会其が委員段を務 好ている化学工学研究要絡委員会が新たに提唱した「地球 生態工学」に関し、提唱に至った経緯及びその学問内柼等 について説明がなされるとともにこの件に関連する，関

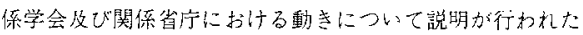

続いて, 大鳥康行第 4 部会員加放, 生物界之地球筑境之 の関わりについて（1生物を媒介にした人閭への影響の問 题をどう捉えるかが，地球環境問題を考えていく上で非常 に重要な観点である。(2)罯境污染が生物資源に与える影管 は非常に大きく、様々な閭題を生し，結局，これか人開に はねかえってくる等の発言があった。

最徭に稲田墑一第 3 部会員加ら，経消活動特に生産活動

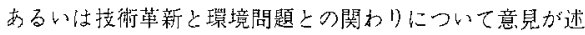
ベられ，環境問題を考之る際には，人間社会が梯乃な技術 をどのように使用寸るかという，人間社会の仕組みの問題 が最毛重要な問題である等の発言があった。

\section{[邻㦈]}

5 人の会員による意見発表の徭行われた討議では，第 1 部から第 7 部まですべての部にわたる20人を超える全崱よ 1，予れぞれ専門の立場から活発学言がなされれ。

この討䔣の中で述べられた意見は多岐多様にわたったが, その主なものを項目にして列挙すると、「コシェネレーショ シに上るエネルギーの有效利用」「IGBP人の人文・社会科 学の関えり方」、海洋と環境問倱」、蓄産廃集物の处理問 题」、「微生物利用による都市河川，下水の净化システム」 「環境問題と人間性との関わり」、「環境問題に对する学術 会議の体制及び取り組み方」「地球環境に関する国際協力 事業についての学術会議が果たすべき役割」等であった。

なおこの総会の自由討議の内容については，後日，日 学双書として出版される予定である。

\section{「委員会報告」3 件を発表}

本会議ては，その意思の表出の形態の一つとして，各部 ・各委員会がその蜜議結果をとりまと好をのを，総会丈 は渾営審議会の承認を得て，外部に発表する「報告、(通称 「対外報告」と言っている。というものがある。
この日本学術会議だよりでも, 今までに,この対外報告 を紹介してきたが，今回，最近発表されたもののうち，ま だ紹介していないる件を，次に紹介する。

\section{電子工学の体系化に向けて一電子・通信工 学研究連絡委員会報告(要旨)}

電子゙工学はそ忋を基整にした通信工学や情報工学, 制御 工学などの急激な進㦼に伴って、これらの技術分野・工学

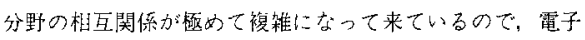
工学の学問・技術体系の恨幹, 電子工学の基盤となってい る方法諭, 通信工学、情報工学等の応用工学とのかかかり を明らかにするた加に方法論的体系化を試みた。

即占電子工学を共通基礎理論, 基礎電子工学, 電子デバ

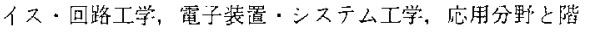
層化し，さらに「集梲回路」上「光エレクトロニクス」が 電子工学の中心分野を形成しうつある重要な技術領域であ るとの認識に立ち電子工学の技術要素々通信工学, 情報工 学との相互関檤を检討した。

また電子工学体系の範囲を大学学部での教育对象分野抽 よU゙大学院での教育を含む研究对象分野に分類した。

「国際防災の十年」一災害科学研究者からの 提言一災害工学研究連絡委員会報告(要旨)

1987年，第42回国連総会で決議された「国際防災の十年」 (IDNDR)のスタートがいよい上迫ってきた。行政レベル では，内閣総理大臣老本部長と京る推進本部が設けられて いるか、ここの実施には科学者，研究者の各専門領域加らの 樍橔的な関与が不可久である。国連決議に先立方，災害工 学研究連絡委資会ではこの活動の支持を表明し，またその 後き米国アカデミーや国連諸機関の活動に協力してきたが, スタートに当たり，わが国の関保科学者，研究者のなすべ き，苏るいは行う得る事柄を提言という形で表明したもの である。交の内容注，(1)国際防災の十年っで何をするのか， (2)匡際共同研究の展開，(3)基碟研究心推進，(4)国際防災の 十年」の実現に向忛て，上り成っている。今㣪はをの実現

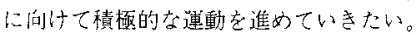

\section{電圧，抵抗および温度の維持方式の 1990年1月1日からの変更についてー 標準研究連絡委員会報告(要旨)}

第77回匡際度量衡委員会(1988年10月開催) 法, 電圧, 抵抗の各椎準の維持方訧の変更々, 温度目盛の変更の 3 つ

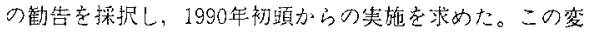

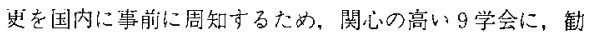
告の裂旨を揭載した。以下に锄告つ骨子を記す。

電王標準はジョセフソン刘果で塞現し，電压周波数係数 を而を記号し，その值を $483597.9 \mathrm{GHz} / \mathrm{V}$ と定義した。抵抗

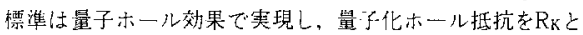
記号しそその值を25812.807日 と定義した。盕度スケール は, IPTS-68に変加り，「TS-90(1990年匡際温度目盛)を定 義した。変更は多岐に的るので，詳細は関連学会誌を参照 されたい。

以上の変更により，電磁気計測の精度と国際的整合性が 著しく改善され，温度計測の熱力学温度との一政と低温域 への摭張か澾成される。

御意見・お問い合わせ等がありましなら，下記ま でお寄せください。

于106 東京都港区六本木 $7-22-34$ 日本学術会議広報委員会 電話03(403)6291 


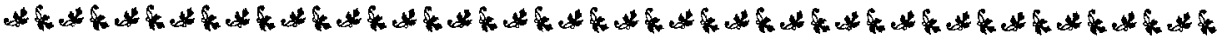

V.

\section{日本医学会だより}

The Japanese Association of Medical Sciences

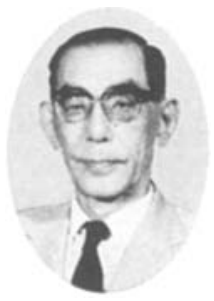

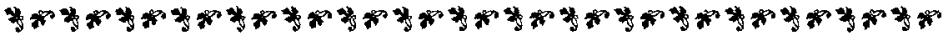

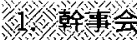

1989 年 9 月 12 日（火）に第 14 回幹事会が開 催され，以下の上らな日本医学会にとって重要 な事項について審議された。

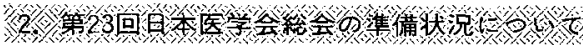

第 23 回総会は，岡本道雄会頭，佐野晴洋・佐 野豊両副会頭, 井村裕夫準備委員長の下で, 1991 (平成 3 ) 年 4 月 5 日から 7 日の3 日間, 京都市に挂いて開催される。

総会のメインテーマは、「転換期に立つ医学上 医療一創造之調和と信頼一」《決定した。シン ボルマークとしては，医学が原点から創造の未 来に我躃するとともに，医学と人間社会との調 和，そして人間の信頼をシンブルに表現したも のが採用された。

な括，学術講演会は，19全助を使用し，宝を 池地区と岡崎地区で行われる．特別講演，シン ポジウム、パネル,教育講演的なミニレクチャー などが予定されている。

展示は，4 カ所以分散して行われ，かなりの スペースで機器の展示が予定されている。

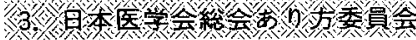

4 年毎の日本医学会総会の間に「中間総会」 を持つことについて，重点的に論議かすすすら れている。
日本医学会昱 太田邦夫

1989年10月 No. 2

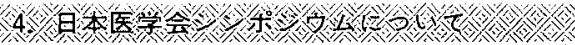

現在，5名のシンポジウム企画委員会委員の 協力の下に，課題を選んでいる.

次回の第 87 回日本医学会シンポシ்ムは,下 記のと拈り開催される(参加希望者は，日本医 学会里で打申迟友下さい).

第87叫日本知学会シンポジウム

主題：スホ犬ーッ医学の今日的課題

曰時：1989年11月28日(火) $9: 30 \sim 17: 30$

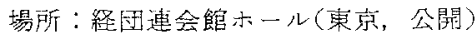

組織委買：黑田善雄(順天堂大・体育) 小野三辟(慈惠医大・生理)

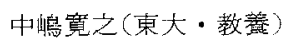
村上正博(聖マ大・们科) 知野 息(日䀢常任理事)

な掉，第 84 回日本医学会シンポジウの「モ デル動物之遺伝子」の記録は，学行書の形で刊 行した。

第 85 回日本医学会シンポジウム「租管内皮細 胞の機能と障害」の記録は，近く刊行の予定で ある(第 85 回日本医学会シンポジゥムの記録を ご希望の万は，日本医学会要で，莱書で打申迟 
み下さい，無料頒布).

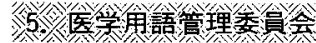

現在，草間委員長，開原副委員長の下で，欧 和版の第 2 版, 和欧版の第 1 版の編集が, 着々 と進行している。

伊前前委員長より引継いだ資料を基礎に検討 が行われた，各委員に，具体的な問題点につい て意見を聞きながら進めている。同義語，反対 語については，できる限り，関連語として採用 する方向である。その他用語の取り上げ万につ いては，各学会の用語委員会との連携を密にし て、学会で採用しているものを使う方針である。 第 2 回委員会に和いて，自治医大・生化学の 香川靖雄教授を招き，意見を伺った。

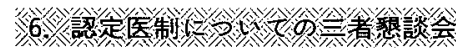

7 月 5 日（水）の第 7 回三者懇談会で，学会 認定医制協議会之日本医師会之の間で，概小了 解した事項は，次のと㧍りである。

(1)まず基本的科目について，認定医公認す る方向で今後推進していく，併せて第 2 段階と して，専門科目について考える。基本科目は， 医師国家試駼科目, 国立大学医学部の講座科目 の中から，小委員会で具体的に決めていく。

(2) 公認の方法として，すす学会が認定し，そ れに対して学会認定医制協議会議長，日本医学 会長，扣よび日本医師会長の三者が追認する形 をとる。

(3) 医療法上の应告表示については, 厚生省と 日本医師会で協議していただく。

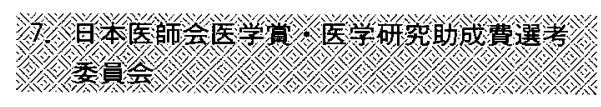

日本医師会上り委託を受けて発足した標記委 員会は，1989年 9 月 12 日（火）に開催された。 平成元年度日本医師会医学賞は，直崎知生教 授(筑波大・薬理) --「平滑筋収縮の分子薬理学 的研究一その構造蛋白質の機能ドメインの研究 とエンドセリンの構造と機能の研究一」, 高久史
管教授（東大・内科）一「造血因子に関する基磯 的・臨床的研究」, 成毛韶夫博士（国立がんセン ター・外科〉一个肺癌のリンパ節転移々外科手術 との相関に関する研究」の3氏に授賞が決定し た.

平成元年度日本医師会医学研究助成費は，井 上芳郎氏，中澤博江氏，森正敬氏，清水不二 雄氏, 斎藤厚氏, 宮園浩平氏, 西岡久寿樹氏, 小林正氏, 北徹氏, 網野信行氏, 早坂 清 氏，田村栄稔氏，桑原慶紀氏，安達惠美子氏， 佐藤 暢氏の15 氏に授賞が決定した。

11 月 1 日の日本医師会設立記念医学大会の 腐上で表彰される。

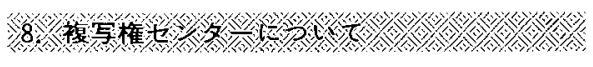

著作権問題については，複写権せンター設立 の禨遭がある.日本工学会が中心になっている。 早い時期から日本医学会をメンバーに入れたい 亡考えられているが，費用の問題等，検討の余 地があり，今な技，日本医学会としては参加し ていない状況である。

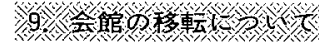

日本医師会館は，文宗区本駒达に明年 2 月に 新館が落成する。乙たがって，平成 2 年 2 月の 第 56 回定例評議員会・第 15 回幹事会（1990年 2 月 27 日・炏, $10: 30$ 一幹事会, $13: 30$ 一評議 員会)は，経団連会館で開催することになる。

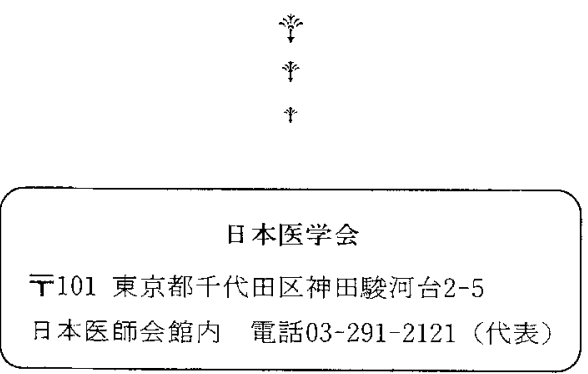

